\title{
THE EFFECT OF SUPERVISION, ENVIRONMENTAL WORK, TRAINING AND LEARNING ORGANIZATION TO THE MANAGERIAL EFFECTIVENESS OF THE HEAD OF HIGH SCHOOL PRIVATE
}

\author{
Nani Kurniasih"' Thamrin Abdullah**, Maruf Akbar***. \\ State University of Jakarta, Indonesia \\ State University of Jakarta, Indonesia \\ State University of Jakarta, Indonesia \\ kurnianani@ymail.com \\ thamrinabdullah@unj.ac.id \\ marufakbar@unj.ac.id
}

The purpose of this research is to know the influence of supervision, work environment, training, learning organization on managerial effectiveness of private high school principal in East Jakarta. This research tries to answer the problem about managerial effectiveness of private high school principals with evidence of quality improvement of school services. The research on the effectiveness of managerial involving 105 private high school principals has been selected from the target population of 83 principals using a quantitative approach with path analysis method. Hypothesis testing research shows: (1) supervision has a positive effect on managerial effectiveness; (2) learning organization have positive effect toward managerial effetivity (3) work environment have positive effect toward managerial effectiveness; (4) job training has a positive effect on managerial effectiveness; (5) the positive impact on the learner organization (6) The positive effect on the learner organization (8) the positive effect on the learner organization (8) the supervision has a positive effect on the work environment; Therefore, to increase managerial effectiveness of private high school principals in East Jakarta. Need to improve supervision, work environment, training and learning organization.

\section{Keywords : Supervision, Work Enviornment, Training, Learning Organization, And Managerial} Effectivitness

Schools as formal educational institutions have a very strategic position in the formation of basic attitudes of learners, therefore in schools need to create a climate and educational environment that is fun, orderly and comfortable. The creation of mission vision is very dependent on the ability of the principal in carrying out his duties as a leader and in managing the educational institution.

Currently the government is focusing on improving the quality of education, the fate of schools and private madrasah actually have difficulty to improve the quality of education. For public schools or private schools that have a strong brand in the community, that is not the case, but it is not the case with private schools of interest to the public. Every new school year is always overwhelmed with worries, unable to capture students in line with expectations. Private Schools must struggle to defend, strive and strive to keep their schools of interest public. Moreover, students prefer public schools rather than choose to study in private schools. Private schools must work hard to improve their management in accordance with the expectations of the community. The problem of the shortage of students which is now experienced by many private schools is one of the causes is the poor managerial ability of the principal. Whereas the principal is required to play the managerial role in ensuring the learning process is going well.

Managerial effectiveness is a measure of the degree to which a manager sets goals to achieve by his organization and the degree to which the organization can achieve those goals. Arikunto (2004: 4) states that supervision can be interpreted as "looking from above" so that it can be interpreted as an activity undertaken by supervisors and employees as officers domiciled above or higher than employees to see or supervise the work of employees. Furthermore, Arikunto asserted that the main activity of supervision is to conduct coaching-to the employee for the quality of work increases. 
In performing supervisory duties a supervisor fostered and assisted the principal in carrying out operational programs to be achieved. The role of supervision as an effort to stimulate, coordinate and guide continuously the development of school principals and schools that led individually and collectively to be more understanding and more effective in realizing all managerial functions.

According to J. Mullins (2005: 264) it can be understood that the effectiveness criteria can be explained through five criteria namely four specific criteria and one general criterion. Specific criteria are those related to the manager's life that are 1) the manager's job that is involved in decision making, problem solving, innovation, time management and information management, 2) personal manager can be motivation, role perception and so on, 3) managerial relationships with others such as subordinates, superiors, clients, handling conflict and leadership, and 4) managers as part of the organization that keep the organization in order to always be conducive, technical and financial control, 5) general categories that include resource allocation, To achieve the objectives and other things of planning, organizing, coordinating and supervision.

In addition, the work environment is also very influential on managerial effectiveness as proposed by Stepen P Robbins (2008: 180) which states that the work environment is everything that is outside the organization that potentially affect employees in the work and ultimately affect the performance of the organization. In other words, the work environment is all beyond the boundaries of the organization but provides support for organizational productivity. The work environment affects the behavior of members of the organization in carrying out its work. Thus, the work environment is created in such a way as to support members of the organization in achieving its objectives.

It cannot be denied that the training aspect is an effect on the success of a managerial effect. According to John M. Ivancevich and Robert Konopaske, (2013: 395) the definition of training is a systematic process of changing employee behavior in a direction that will achieve organizational goals. Training related to presenting work skills and abilities. It has a current orientation and helps employees master the skills and abilities needed to be successful.

To always improve performance in a sustainable and cyclical manner, it takes individual commitment and competence to learn and share knowledge at the superficial and substantial levels. The learning organization is the key to answering a challenge in managerial effectiveness. According to DuBrin, Andrew J. Certo (2012: 79) explains that learning organization is a learning organization that is good at creating, obtaining, and transferring knowledge, and changing behavior to reflect new knowledge. The keywords of a learner's organization are learning which in essence creating, acquiring and transferring knowledge is so that it looks a change reflecting new knowledge.

So the managerial success of the principal in an organization is also not free from a conducive environment in the workplace. Usually the working environment is quite interesting, then the performance of employees concerned will be better. Similarly, teachers as educators, to improve its performance requires a harmonious work environment, compact, mutual understanding, mutual help, and always tolerance of fellow educators in order to advance the school.

\section{METHOD}

This study aims to determine whether or not the influence of supervision, work environment, training, and learning organization on managerial effectiveness. This research uses survey method with causal approach, and this research is quantitative associative by using path analysis. The research population is headmaster and private high school teacher in Jakarta amounted to 105 teachers and the sample is 83 principals. Data collection using questionnaire instruments designed to resemble the scale of Linkert on a scale of 1-5. Based on the results of the study of the theories, researchers developed the following model. 


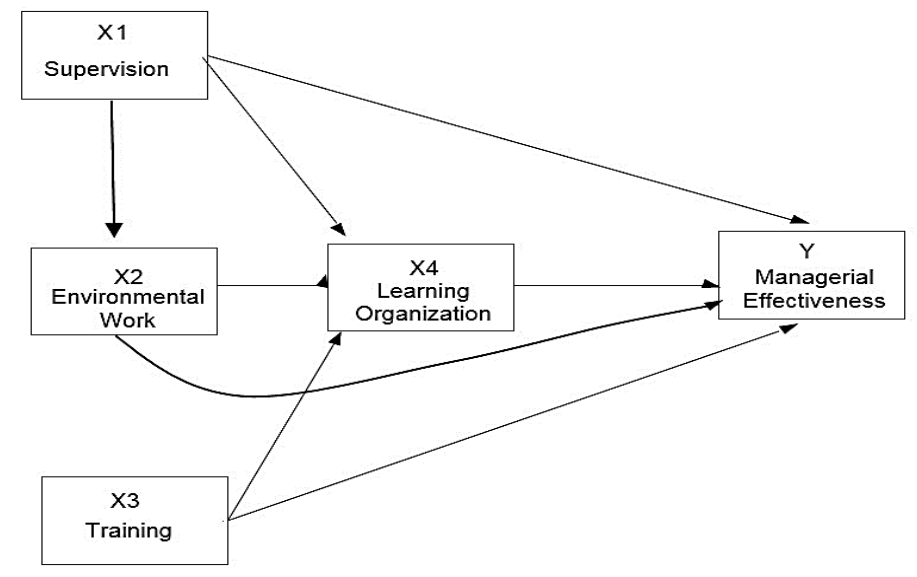

Figure 2.1: Constellation Model

Explanation:

$\mathrm{X} 1=$ Supervision

$\mathrm{X} 2$ = Environmental Work

$\mathrm{X} 3$ = Training

$\mathrm{X} 4$ = Learning Organization

$\mathrm{Y}=$ Managerial Effectiveness

\section{Result and Discussion}

\section{Supervision directly affects the managerial effectiveness of principals in private high} schools in East Jakarta

Based on the results of research that has been done can be explained that the direct positive and significant direct impact on managerial effectiveness, in the study found a picture that empirically strong supervision can improve managerial effectiveness Principal. Implementation of supervision or supervision in every school has an important role. Supervision as a process to apply what work has been done, assess it and if necessary correct with the intention that the implementation of work in accordance with the original plan. Supervision is done in every line of the organization, including organizations within the education sphere, one of which is the school. Principals and supervisors have a strategic role in providing assistance and stimulating teachers and employees in maintaining a better learning environment.

Educational supervision activities have various functions. Supervision of education will be done well when its functions are able to be applied properly so it can be concluded that effective supervision is giving good contribution and very influential for the creation of effective managerial and conducive learning environment, this is according to the opinion of Kilminster SM, Jolly BC; "An aspect of teaching and learning in education is the process of supervision and influence of effective in education." The principal's managerial effectiveness is the essence of management, therefore a leader must have and execute his leadership well in order to gain success in performing his or her duties. A leader expects the teacher to complete the job properly, effectively and efficiently in accordance with the intended purpose, but if it cannot solve well, it is necessary to know the reasons.

There is a possibility that teachers are having difficulties in completing their tasks, due to work environment factors that result in the decreasing effectiveness of teachers' work. In the implementation of private high schools in East Jakarta, the managerial effectiveness of principals 
greatly affects the performance of teachers and staff, so in some studies this greatly affects the success rate of a teacher completing the process of teaching and learning in the classroom. This is also in accordance with the results of the research Miswan, 2005, the influence of supervisory behavior, organizational climate and work motivation on the performance of civil servant teachers in high school in Bandung (studies in the Department of private universities in Bandung), the results showed the supervision effect Positive and significant to the performance of civil servant teachers.

Organizational climate has positive but insignificant effect, while teacher work motivation has positive and significant effect on civil servant teacher performance at Bandung High School. The conclusion of this research is that the behavior of supervision, organizational climate and work motivation are the strategic factors to realize the performance of Effective civil servant teachers and qualified school managerial. From the above it can be explained that the results of the research are different from the results of previous research can be explained that supervisory supervision can affect the effectiveness of managerial Principal, in managerial effectiveness, the role of leader or principal not only as the task giver and authority to the teacher but preparing the teacher in implement the learning process well. The principal not only oversees but becomes the executive of the policy, and he also has a high commitment in implementing the vision and mission of the school program.

Effective supervision can improve the Principal's managerial effectiveness among others. First, support teachers to innovate in learning, create a comfortable atmosphere and effective learning, in addition the principal provides facilities and information to cooperate with one another. Second, direction, the principal has shown practical solutions in the learning process, and provide direction on the task and work of the teacher. Third, participation, Principals participate actively in community service, research and dissemination of science, Principals provide feedback to teachers about suggestions and complaints, give advice to work. The principal conveys clear information about teachers who are accomplished and diligent in the learning process, listens to teacher complaints and seeks out solutions to keep teachers doing well in the Tri Dharma School or in the learning process, and Principals provide support to make teachers more self-reliant And perform well in the internal school or out of school it's all because of its effective personality and it all can improve the ability to excel in work as Amjad Ali's opinion; "Personal Effectiveness" inspires managers to continuously develop and upgrade their set of skills, knowledge and behaviours to be appropriate for effective leadership in the 21st century. Personal Effectiveness' introduces managers to the idea of effective performance and the underlying techniques and approaches required in terms of behaviour and skills to achieve effective performance.

Personal Effectiveness "Inspires managers to continue to develop and improve their skills, knowledge, and behavior to fit effective leadership in the 21st century. The personal effectiveness of managers' introduction to effective performance ideas and the fundamental techniques and approaches needed in relation to behaviors and skills to achieve Effective performance in this case is as a supervisor at the school. From the above it can be clarified that in improving the effectiveness of the managerial Principal of private schools that need to involve the existence of bright ideas, techniques and all elements, therefore leaders in strengthening managerial effectiveness by applying management functions well such as planning, organizing, And monitoring, communication effectively, giving way to achievement in teachers, consistent and motivated in making changes. School will not happen without an active supervision in controlling the school with a consistent strategy so that its supervision has influence in the learning process at school.

\section{Learning organizations directly influence the effectiveness of Managerial Head of Senior High School in Jakarta}

The organizational leader's greatest challenge is that the current headmaster is concerned with trying to cope with a rapidly changing environment. Technological advancements and 
innovations in various fields, especially Information and Communication Technology (ICT) bring globalization that makes the world not as in the previous era. As a result, management principles and guidelines that make the organization more stable and predictable can no longer be applied for long periods of time. The success of the organization at this point depends largely on the organization's ability to learn and respond to rapid changes. Highly Learner organizational concepts are needed to implement learner organizations to develop individual and organizational capabilities, and change the paradigm of "person-job fit" to "person-organization job".

In this case, including the roles and responsibilities of leaders to support the success of learning organizations, so that the learning organization is expected to create a conducive environment for management and organization as a whole. Learning organization is a concept where the organization is considered capable to continuously perform self-learning process so that the school organization has the speed of thinking and acting in response to various changes that arise. A learning organization is an organization that facilitates learning from all its members and constantly transforms itself. The purpose of the use of individual learning process, group or organizational, is to transform the organization to meet stakeholder satisfaction.

The success of the principal in an effort to improve the effectiveness in managerial in the school is influenced by learning organization training, environment and supervision ever done by the citizens of the school. This supports the opinion expressed by Petter Senge; "In learning organization requires ability, motivation to learn adaptive, generative, and sustainable. Learning within the organization will be more rapid if people want to share insights and learn together. Share insights of knowledge within team is very important and influence to increase managerial effectiveness within the organization".

The principal's managerial ability is an important and strategic factor in the framework of improving the quality and progress of the school he leads. With managerial capability, both technical ability, humanitarian ability, and adequate conceptual ability, the principal is expected to be able to move all potential in school including to improve the quality of teacher performance in the school. With qualified teachers, the learning process will take place optimally. Furthermore, school is advanced and great if the school is protected from the pressures of various parties. The spirit of work, enthusiasm, motivation, and so forth will be well created if the school has a leader who is able to manage and mentor well his institution.

Changes in the structure and type of manpower required by the labor market are a source of inspiration for principals and teachers to make innovative decisions sourced from learning organizations. Managers of an organization generally only know what their task is for the process in the organization can continue. However, rarely among those who know how to act against the ongoing changes. Rarely are able to anticipate changes that will occur in society in general and in organizations in particular. Rarely are they innovating, putting up new strategies as a result of their anticipation.

Though the job is their duty which in general they are immersed in the routine task for the smooth movement of the organization and the success of this routine task that they are pursuing. Leadership in the context of school emphasizes more on the relationship between school personnel and creating a climate of togetherness and mutual ownership that is characterized by a sense of togetherness in work. Under such conditions will create a harmonious relationship among all school personnel, staff are encouraged to learn future, with a clear hierarchy within the organization in accordance with Craigh Jonsong views in the first and second-order models in the learning organization: 


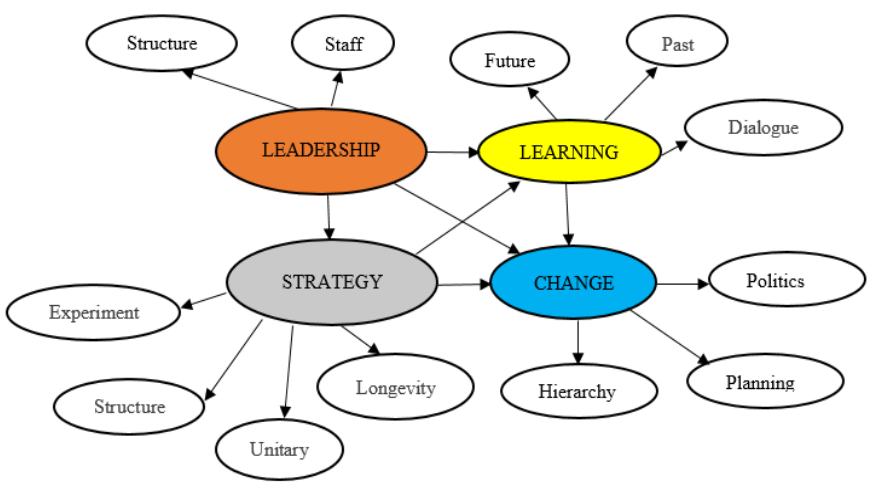

Figure 1: First and Second Order Model on the Learning Organization

Figure 3.1 shows the first- and second-order path diagrams. Thus leadership is driven by latent variables that have been named structures and staff. Learning is driven by constructs that have been named future, past and dialogue. Strategy is driven by latent variables that have been named experiment, structure, unitary and longevity. Finally change is driven by latent variables that have been named hierarchy, planning and politics. These first-order constructs will be explained below.

Successful leadership moves subordinates depends on their ability to influence subordinates to work well also depends on the learning organization in the school. Referring to the above results it can be seen that in general the headmaster managerial ability is good enough. The ability of the principal to play a role as a school manager is crucial to determining the achievement of the stated school goals. This is in accordance with the opinion of Euis Karwati and Donni who stated that the principal's managerial skills are related to the effort to realize the educational objectives effectively and efficiently, three things related to the principal's managerial skills are process, school resources, and goal achievement. With good managerial skills, it is expected that the achievement of school goals will be achieved.

The result of statistical test can reinforce the theory that has explained that the learning organization has a direct positive effect on managerial effectiveness, meaning that the better the learning organization the more effective the manager of the principal in managing all educational activities.

\section{Work Environment Positive Direct Influence on Managerial Effectiveness}

Work environment is a condition around the workplace that affects employees perform activities both physically and nonphysical. A good working environment encourages employee morale so as to improve employee performance. A good work environment and fun for employees viewed from the existence of harmonious relationships that give mutual support among colleagues, in addition supported by the condition of a good work space and adequate work equipment.

A conducive working environment can also encourage organizational managerial effectiveness, enhance work morale and a high work ethic through trainings. So it can be said that the environment can affect the managerial effectiveness of the principal in managing and improving the quality of school. Opinions Olukunle S. Oludeyi which states; "Conducive workplace environments give pleasurable experiences to the employees and help them actualize in the dimensions of personality profile while toxic workplace environments give painful experiences and de-actualize employees' behaviour. Kyko believes that irresponsible or uncommitted employees can 
change to be responsible and be more committed to job in conducive work environment because such environments reinforce the self-actualizing traits in them.

A conducive work environment provides an enjoyable experience for employees and helps them actualize the personality profile dimension while the toxic workplace environment provides a painful experience and does not actualize employee behavior. Kyko believes that irresponsible or unbound employees may change to be responsible and more committed to work in a conducive environment because such an environment reinforces the nature of self-actualization within it.

It strengthens and reinforces the results of statistical testing theory has explained that the working environment has direct influence positively to managerial effectiveness, meaning that the more comfortable and conducive working environment, the more effective managerial Principal in managing all educational activities.

\section{The Training Had a Direct Effect on the Managerial Effectiveness of Headmaster of Senior High School in Jakarta}

Training is an activity that intends to improve and develop attitudes, behavior skills, and knowledge of employees in accordance with the wishes of the company. Thus, the intended training is training in a broad sense, not limited only to developing skills solely. In addition, training is also a systematic process whereby employees learn knowledge, skills, ability or behavior against Personal and organizational goals. According to Drummond useful to guide and guide the development of trainees through the knowledge, skills and attitudes gained to meet certain standards.

With the training also someone will try to adapt someone to his environment, whether it is environment outside work, and environment in it. The objective is to improve employee skills in accordance with technological change, to reduce the learning time for new employees to become competent, to assist operational issues, to prepare employees in promotions, to orient employees to get to know their organization. If a well-planned development training program will benefit people in terms of increased productivity, increased morale, cost reduction, and greater stability and flexibility to adapt to changing external requirements, it is also beneficial to increased headmaster effectiveness of headmasters at private high schools in East Jakarta.

So training has a very important role for the organization and contributes to these three key issues in Hamalik's opinion: "Training has the potential to improve labour productivity, Training and development can improve the quality of that output: a more highly trained employee is not only more competent at the job but also aware of the significance of his organization her actions, Training and development improves the ability of the organization to cope with change ; the successful implementation of change whether technical (in the form of new technologies) organization strategic new products, new markets, etc) relies on the skills of the organization's member. Training is importation for the survival of any organization. It is also imperative for effective performance of employee's enhancement of employees' ability to adapt to the changing and challenging business environment and technology for better performance, increase employees knowledge to develop creative and problem solving skills.

The contribution of the training is to improve school management performance for the principal and to improve the effectiveness of the principal's manager in improving the quality and quality in the learning process in the classroom. This in accordance with statistical test results can reinforce the theory that has explained that the training directly affects positively to managerial effectiveness, meaning that the better the training the more effective the Headmaster manager in managing all educational activities.

\section{Supervision Directly Affects the Learning Organization}

Supervision is a supervisory activity but it is more humanity or humane. Supervision activities are not looking for faults but are more of an apportioning element, so that the condition of 
the work under supervision can be known to be deficient (not merely a mistake) in order to be told which parts need to be fixed. Supervision is done to see which parts of the school activities are still negative to be pursued to be positive, $\&$ see which one is positive to be improved to be more positive again and the most important is the coaching.

The categories of supervisors in education are principals, school inspectors, and district level supervisors, as well as staff in the field offices in each province. If supervision is carried out by the school supervisor, he or she may undertake various oversight and controls to improve the performance of principals, teachers and education personnel as well as in learning organizations. Good supervision is the supervision that is capable of functioning to achieve the above multi purposes. There is no success for supervision if only paying attention to one particular goal to the exclusion of another.

It is only by reflecting on these three objectives that supervision will function to change the behavior of the principal's managerial teaching. In turn later changes in teacher teaching behavior toward a higher quality will lead to better student learning behavior. While supervision behavior is directly related and affect the behavior of principals. This means that, through supervision, supervisors influence teacher teaching behavior so that the behavior is better in managing the teaching and learning process.

Furthermore the good managerial behavior of the principal will affect teacher's teaching behavior and student learning behavior. Thus, it can be concluded that the ultimate goal of supervision is the fostering of better student learning behavior. Supervision and control is a control for educational activities in schools directed to the goals that have been set. Supervision and control is also a preventive measure to prevent educational personnel from doing irregularities and more careful in carrying out their work.

The learning organization is a concept whereby the organization is perceived to be capable of continuously performing the self-learning process so that the organization has a 'speed of thinking and acting' in responding to the various changes that arise. According to Pedler, Boydell and Burgoyne that the learning organization is an organization that facilitates the learning of all its members and constantly transforms itself. Learning is an activity aimed at the acquisition and development of skills and knowledge and its application. According to carol the most conceptual of learning organization is the assumption that 'learning is important', sustainable, and more effective when it is shared and that each experience is an opportunity to learn.

According to Peter Senge the key to achieve this type of organization. Peter Senge also emphasizes the importance of dialogue within organizations, especially with regard to the team learning discipline. So dialogue is one of the characteristics of every real conversation that everyone exposes himself to others, actually accepts his point of view as a valuable consideration and enters the other in the limits that he understands not as an individual in particular, but the content of his speech. The goal is not to win the argument but for further understanding. Team learning requires the capacity of group members to uproot the assumptions and enter into the true thinking together pattern. The shared thinking and learning of the team is also influenced by the supervision performed by both the supervisor, the overseer, and the principal.

This is reinforced by the results of statistical testing can strengthen the theory that has explained that supervision directly affects positively to the learning organization, which means the better the supervision of the more effective the principal manager in managing the learning organization.

\section{The Work Environment Directly Affects the Learning Organization}

Work environment is something that is around teachers and employees who influence themselves in carrying out tasks that are charged work environment is the whole tooling tools and materials encountered, the environment around which a person works, methods of work, and 
arrangement of work either as individuals or as a group. Work environment conditions are said to be good or appropriate if humans can carry out activities optimally, healthy, safe, and comfortable. The suitability of the working environment can be seen as a result in the long term furthermore poor working environments may demand more labor and time and do not support the efficient design of work systems.

The work environment is part of the social, psychological, and physical life of the school that affects workers in performing their duties. Human life cannot be separated from the various circumstances surrounding environment, between humans and the environment there is a very close relationship. In this case, humans will always try to adapt to various circumstances surrounding environment. Similarly, when doing the job, principals as human beings cannot be separated from various circumstances around where they work, namely the work environment. During the work, every employee will interact with the various conditions contained in the work environment. According to Bambang the work environment is one of the factors that affect the learner's organization and the performance of an employee.

An employee who works in a work environment that supports him to work optimally will produce good performance, otherwise if an employee working in an inadequate work environment and not support to work optimally will make the employee concerned to be lazy, tired so that the performance employee will be low. It's a brown opinion that; "Work environment direct impact to employees themselves and their work, and also has implications for the effectiveness learning organization in schools".

This opinion is also in line with the opinion of Peter Senge who argued that in an effective learning organization will enable the organization to learn, develop, and innovate. So it can be concluded that the work environment has a direct effect on the creation of a good learner organization. This reinforces the results of statistical testing can reinforce the theory that has explained that the work environment directly affects positively to the learning organization, meaning that the better the work environment the more effective the manager of the principal in managing the learning organization.

This reinforces the results of statistical testing can reinforce the theory that has explained that the work environment directly affects positively to the learning organization, meaning that the better the work environment the more effective the manager of the principal in managing the learning organization.

\section{Training Has a Direct Effect on the Learning Organization}

The results showed that the school as a learning organization is still low category due to the lack of team learning and share monitoring efforts, the school as a learning organization contributes to the learning achievement of $1.7 \%$, the school as a learner organization contributes to the student attachment of 9, 4\%.Although the above figures are still low category but based on the number of factors that affect the achievement of learning and school quality so these factors still have an important value.

Educational organizations as learning organizations concentrate on improving the work process (improve work process). This is influenced by the training process for teachers or employees. Training is the expectation of every employee. That requires the creation of quality in work and create a sense of fun in work, so that physical and psychological needs can be accommodated. Training has many implications for the attitudes and behaviors of teachers and employees in learning organizations in schools. It is supported by Fetter who said that; "Training is one of the several mechanisms that directly affect the individual learning organization, performance and managerial effectiveness".

In addition, Training will also encourage teachers and employees to remain loyal because of what the organization is expected to meet. This attitude is nothing but a reflection of employees who 
have been trained in their organization, therefore, it can be understood if the training affects the learning organization. This is reinforced by the results of statistical testing can reinforce the theory that has explained that training has a direct positive effect on learning organizations, meaning that the better the training the more the learning organization in education.

\section{Supervision Directly Affects the Work Environment}

Supervision is an effort to help principals, teachers and employees in developing their ability to achieve learning objectives. The essence of supervision is by no means assessing the performance of principals, teachers and employees in managing the learning process, but helps principals, teachers and employees develop their professionalism skills.

Supervision directly influences and develops the principal's behavior in managing education in schools. This is the essential characteristic of supervision. In this regard, it should not be assumed narrowly, that there is only one best way that can be applied in all principal managerial development activities. There is no good supervisory behavior and is suitable for all principals, teachers and employees.

Strictly speaking, the level of ability, needs, interests, and professional maturity and other personal characteristics of the headmaster become the basis of consideration in developing and implementing the supervision program. The supervisor's behavior in helping principals, teachers or employees develop their abilities should be designed in an official manner, making it clear that the start and end time of the development program. The design manifests in the form of a supervision program that leads to a specific purpose.

The development of professionalism skills in this context should not be narrowly interpreted, solely emphasized on improving the knowledge and skills of teaching principals, teachers and employees, but also on improving the commitment or willingness or motivation of teachers, because by increasing the ability and motivation of teachers work, the quality of learning will increase.

And in the implementation of educational supervision, as a supervisor must know and understand and implement techniques in supervision. Various techniques can be used by supervisors in helping teachers improve teaching and learning situations, either in groups or individually or by face-to-face and face-to-face or in-depth communication media either outside or in the school's work environment.

Work environment is one of the factors that affect the performance of an employee. An employee working in a work environment who supports her to work optimally will result in good performance must be strengthened with supervise in order to create a good working environment, work environment is divided into two, the physical work environment is all physical circumstances that are around the workplace Can affect employees either directly or indirectly.

Non-physical work environment is all the circumstances that occur related to the relationship work, either with the boss, or relationships with colleagues or relationships with subordinates. The above can be concluded that the supervision made by the suvervisor can affect the work environment. This is reinforced by the results of statistical testing can strengthen the theory that has explained that supervision directly affects positively to the work environment, meaning the better the supervision the better and conducive work environment. The results of statistical constraints obtained direct path coefficient of supervision on managerial effectiveness $\left(\mathrm{P} \gamma_{1}\right)=0.429, \mathrm{t}$ arithmetic $=84.778$ and $\mathrm{Sig}=0,000<0.05$.

Thus it can be concluded that supervision has a direct positive effect on managerial effectiveness. The direct influence of the learner's organization on managerial effectiveness $(\mathrm{P} \gamma 4)=$ $0.403, \mathrm{t}$ arithmetic $=87.465$ and $\mathrm{Sig}=0,000<0.05$. This means that the learning organization has a positive effect on managerial effectiveness. For direct effect of training on managerial effectiveness got coefficient of path $\left(\mathrm{P} \gamma_{3}\right)=0,640, \mathrm{t}$ count $=53,170$ and $\mathrm{Sig}=0,000<0,05$. 
This means that training has a direct positive effect on managerial effectiveness. Next to direct influence of supervision on learning organization got coefficient of path $\left(\mathrm{P}_{41}\right)=0,595$, $\mathrm{t}$ count $=63,723$ and $\mathrm{Sig}=0,011<0,05$. Thus it can be concluded that supervivi have a direct positive effect on learning organization. For direct influence of work environment on learning organization $\left(\mathrm{P}_{42}\right)=$ $0,303, \mathrm{t}$ arithmetic $=109,074$ and $\mathrm{Sig}=0,000<0,05$.

This means that the work environment has a positive effect on the learning organization. While for direct influence of training on learning organization got coefficient of path $\left(\mathrm{P}_{43}\right)=0,403, \mathrm{t}$ arithmetic $=106,173$ and $\mathrm{Sig}=0,000<0,05$. This means that the training has a direct positive effect on the learning organization.

Finally for the influence of supervision on the work environment obtained coefficient path $\left(\mathrm{P}_{31}\right)=0.257, \mathrm{t}$ arithmetic $=110.104$ and $\mathrm{Sig}=0,000<0.05$. Thus it can be concluded that the supervision has a direct positive effect on the work environment. For direct influence of work environment on training $\left(\mathrm{P}_{32}\right)=0,252$, $\mathrm{t}$ count $=119,017$ and $\mathrm{Sig}=0,000<0,05$. This means that the work environment has a positive effect on the training.

In a comprehensive regression equation can be seen in the summary results of $F$ test calculations for determination of significance and linearity in Table 1.

Table 1 Summary of Regression Linearity Test Results

\begin{tabular}{|c|c|c|c|c|c|}
\hline \multirow{3}{*}{ Variabel } & \multirow{3}{*}{ Equation } & \multirow{3}{*}{$\begin{array}{l}\text { Test } \\
\text { F hitumg }\end{array}$} & \multirow{2}{*}{\multicolumn{2}{|c|}{$\begin{array}{c}\text { Linearity } \\
F_{\text {tabel }}\end{array}$}} & \multirow{3}{*}{ Conclusion } \\
\hline & & & & & \\
\hline & & & $\alpha=0,05$ & $\alpha=0,01$ & \\
\hline \multirow[t]{2}{*}{$\mathrm{Y} \operatorname{atas} \mathrm{X}_{1}$} & $\mathrm{Y}=84,783+0,429 \mathrm{X}_{1}$ & 15.905 & 3.96 & 6.96 & Significant \\
\hline & & 2,805 & 3,44 & 4,88 & and Linear \\
\hline \multirow[t]{2}{*}{$\mathrm{Y}$ atas $\mathrm{X}_{4}$} & $\mathrm{Y}=87,465+0,403 \mathrm{X}_{2}$ & 20.951 & 3.96 & 6.96 & Significant \\
\hline & & 2,810 & 3,44 & 4,88 & and Linear \\
\hline $\mathrm{Y} \operatorname{atas} \mathrm{X}_{2}$ & $\mathrm{Y}=119,017+0,252 \mathrm{X}_{2}$ & $\begin{array}{r}13,622 \\
2872\end{array}$ & $\begin{array}{l}3.96 \\
3.44\end{array}$ & 6.96 & Significant \\
\hline \multirow[t]{2}{*}{$\mathrm{Y}$ atas $\mathrm{X}_{3}$} & $\mathrm{Y}=53,170+0,640 \mathrm{X}_{3}$ & 28.729 & 3.96 & 6.96 & Significant \\
\hline & & 2,831 & 3,44 & 4,88 & and Linear \\
\hline $\mathrm{X}_{4}$ atas $\mathrm{X}_{1}$ & $\mathrm{X}_{4}=63,723+0,595 \mathrm{X}_{1}$ & $\begin{array}{r}35.1552 \\
858 \\
\end{array}$ & $\begin{array}{l}3.96 \\
3,44 \\
\end{array}$ & $\begin{array}{l}6.96 \\
4,88 \\
\end{array}$ & $\begin{array}{l}\text { Significant } \\
\text { and Linear }\end{array}$ \\
\hline $\mathrm{X}_{4} \operatorname{atas} \mathrm{X}_{2}$ & $\mathrm{X}_{4}=109,074+0,303 \mathrm{X}_{2}$ & $\begin{array}{r}16.2532 \\
872\end{array}$ & $\begin{array}{l}3.96 \\
3,44\end{array}$ & $\begin{array}{l}6.96 \\
4,88 \\
\end{array}$ & $\begin{array}{l}\text { Significant } \\
\text { and Linear }\end{array}$ \\
\hline $\mathrm{X}_{4} \operatorname{atas} \mathrm{X}_{3}$ & $\mathrm{X}_{4}=116,008+0,257 \mathrm{X}_{3}$ & $\begin{array}{r}13,412 \\
2,822 \\
\end{array}$ & $\begin{array}{l}3.96 \\
3,44 \\
\end{array}$ & $\begin{array}{l}6.96 \\
4,88 \\
\end{array}$ & $\begin{array}{l}\text { Significant } \\
\text { and Linear }\end{array}$ \\
\hline $\mathrm{X}_{2} \operatorname{atas} \mathrm{X}_{1}$ & $\mathrm{X}_{4}=110,104+0,257 \mathrm{X}_{3}$ & $\begin{array}{r}16,5532 \\
858\end{array}$ & $\begin{array}{l}3.96 \\
3,44\end{array}$ & $\begin{array}{l}6.96 \\
4,88\end{array}$ & $\begin{array}{l}\text { Significant } \\
\text { and Linear }\end{array}$ \\
\hline
\end{tabular}

Explained the structural model under test consists of three sub-structural equations can be seen in the following results;

Sub-structural equation 1: the result of path coefficient calculation got direct influence of supervision path, work environment and training to managerial effectiveness.

$\mathrm{Y}=\mathrm{Py} 1 \mathrm{X} 1+\mathrm{Py} 4 \mathrm{X} 4+\mathrm{Py} 2 \mathrm{X} 2+\mathrm{Py} 3 \mathrm{X} 3+€ 3$

$\mathrm{Y}=0,219 \mathrm{X} 1+0,247 \mathrm{X} 4+0,247 \mathrm{X} 2+0,408 \mathrm{X} 3+€ 3$

Sub structural equation 2: The result of path coefficient calculation got direct influence of supervision path and work environment of training to learning organization.

$\mathrm{X} 4=\mathrm{P} 4 \mathrm{XX} 1+\mathrm{P} 42 \mathrm{X} 2+\mathrm{P} 43 \mathrm{X} 3+€ 2$

$\mathrm{X} 4=0,289 \mathrm{X} 1+0,202 \mathrm{X} 2+0,436 \mathrm{X} 3+€ 2$

Sub structural equation 3: The result of path coefficient calculation got direct influence of supervision to work environment.

$\mathrm{X} 2=\mathrm{P} 21 \mathrm{X} 1+€ 1$

$\mathrm{X} 2=0,546 \mathrm{X} 1+€ 1$ 
The path coefficient and $t$ value can be seen in the following path diagram:

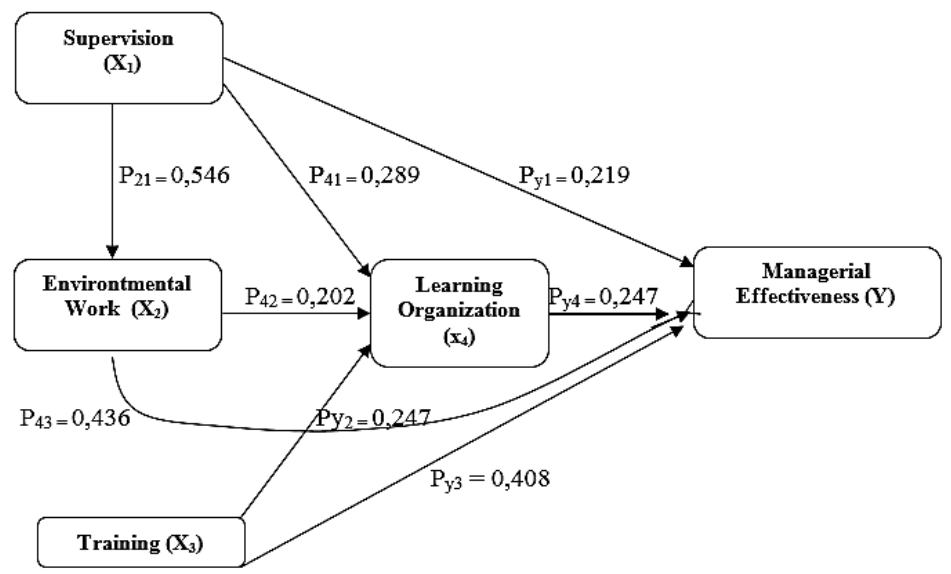

Figure 2 The coefficient of path and $t$ value $Y$ influenced X1, X2, X3, and X4.

\section{CONCLUSION}

Supervision has a direct positive effect on the effectiveness of management. Meaning that good Supervision can lead to increased effectiveness of management in schools. Learning organizations have a direct positive effect on the effectiveness of management, meaning that strong academic community learning organizations in schools can lead to increased management effectiveness. Training has a direct positive effect on management effectiveness. Meaning that strong training can lead to increased management effectiveness.

Supervision has a positive direct effect on the learning organization. Meaning that great Supervision can lead to changes in learning organizations that have an impact on the creation of an educational atmosphere in the School. The work environment has a direct positive effect on the learning organization, meaning that a comfortable work environment can lead to changes in a great learner organization. The training has a direct positive effect on the learning organization.

This means that continuous and reliable training can lead to the creation of a good learner organization. Supervision has a positive direct effect on the work environment. Meaning that strong supervision can create a good working environment. The work environment has a positive direct impact on the training. Meaning a comfortable working environment can lead to improved training.

\section{REFERENCES}

Barclays Offshore Banking, What Does Work Environment Mean? http://www.blurtit.com/a424306. html (Accessed 3 April 2016).

Certo, Samuel C. (2012). Modern Management: Concepts and Skills. New Jersey: Prentice Hall, $12^{\text {th }}$ Edition.

Collin P. Silverthorne. (2005). Organizational Psycohology in Cross Cultural Perspective. New York: New York University.

Dadang Suhardan. (2010). Supervisi Profesional (layanan dalam Meningkatkan Mutu Pengajaran di Era Otonomi Daerah). Bandung: Alfabeta.

Daft, Richard L. and Dorothy Marcic. (2009). Understanding Management. Mason: Cengage Learning, Sixth Edition.

Daft, Richard L. (2010). Organization Theory and Design. Mason: Cengage Learning, Tenth Edition.

DuBrin, Andrew J. (2012). Essentials of Management. Mason: Cengage Learning, Ninth Edition.

Fred Luthans, Jonathan P. Doh. (2012). International Management: Culture, Strategy, and Behavior. New York: McGraw Hill, 8th Edition. 
George, Jennifer M., Gareth R. Jones. (2012). Understanding and Managing Organizational Behavior. New Jersey: Pearson Press, Sixth Edition.

Glickman, C.D. (1981). Developmental Supervision Alternatif Practices for Helping Teacher Improve Instruction. Alexandria. Virginia: ASCD.

Gomez, Mejia, Luis R., David B. Balkin. (2012). Management. New Jersey: Prentice Hall.

Greg L Stewart. (2011). Human Resource Management, Linking Strategy to Practice. Danvers: John Wiley \& Sons, Inc, Second Edition.

J. Lourie Mullins. (2005). Management and Organizational Behavior, Seventh Edition. USA: McGraw-Hill.

Jack Dunham. (2005). Developing Effective School Management. New York, USA Taylor \& Francis e-Library.

Jerald Greenberg and Robert A.Baron. (2008). Behavior in Organization. New Jersey: Pearson Education Educational.

John M. Ivancevich and Robert Konopaske. (2013). Human Resource Management Twelfth Edition. New York: Mc.Graw-Hill International Edition.

John R. Schermerhorn. (2014). Managing Organizational Behavior. New York: John Wiley and Sons.

Laurie J. Mullins. (2010). Management and Organizational Behavior. Edinburgh Gate, Harlow: Prentice Hall.

Luis R.Gomes, David B.Balkin and Robert L.Cardy. (2010). Managing Human Resources. New Jersey: Global Edition, Pearson.

Michael Armstrong. (2009). Handbook of Management and Leadership: A Guide to Managing For Results. London: Kogan Page Limited, Second Edition.

Mullins, Laurie J. (2010). Management and Organisational Behaviour. Essex: Pearson Education Limited, Ninth Edition.

Mulyasa, E. (2004). Menjadi Kepala Sekolah Profesional. Bandung: PT Remaja Rosda Karya.

Noe, Raymond A. 2011. Fundamentals of Human Resource Management. New York: McGraw Hill, $4^{\text {th }}$ Edition.

Pamela S. Lewis. (2007). Management: Challenges for Tomorrow's Leaders. Mason: Thomson South-Western, 5th Edition.

Peter F. Drucker. (2001). The Effective Executive. New York: Harper \& Row.

Raymond A. Noe. (2010). Employee Training and Development. New York: McGraw-Hill, $5^{\text {th }}$.

Reddin L. Daft. (2001). Managerial Effectiveness. New York: McGraw-Hill.

Richard L. Daft. (2010). New Era of Management. South Wester: Cengage Learning.

Robbins, Stephen P \& Mary Coulter. (2012). Management. New Jersey: Prentice Hall, $11^{\text {th }}$ Edition.

Robbins, Stephen P \& Timothy Judge. (2009). Organizational Behavior. New Jersey: Pearson International Edition, $13^{\text {th }}$ Edition.

Robert E. Franken. (2000). Human Motivation. California: Brooks Publishing Company.

Robert Kreitner. (2009). Management. Boston: Houghton Mifflin Harcourt Publishing, Eleventh Edition.

S. Balaraman. (1989). Are Leadership Styles Predictive of Managerial Effectiveness, Indian Journal of Industrial Relations, Vol. 24, April.

Sahertian, P.A, dan Mataheru, F. (1981). Prinsip dan Teknis Supervisi Pendidikan. Surabaya: Usaha Nasional.

Sergiovanni. T.J, and Starrat, F.D. (1980). The School Executive: A Theory of Administration $2^{\text {nd }}$. New York: Harper and Row Publishers.

Stephen P. Robbins. (2008). Organizational Behavior: Concept, Controversies, and Application. New Jersey: Prentice-Hall.

Syaiful Sagala. (2010). Supervisi Pembelajaran dalam Profesi Pendidikan. Bandung: Alfabeta.

Terence Jackson. (1995). Cross Cultural Management. Oxford: Butterworth Heinemann Ltd.

Wagner, John A \& John R. Hollenbeck. (2010). Organizational Behavior: Securing Competitive Advantage. Oxon: Routledge.

Warren Schmidt H \& Jerome P. Finnigan. (1993). Total Quality Manager A Practical Guide for Managing in a Total Quality Organization, San Fransisco: Jossey.

Wiles, K. (1967). Supervison for Better School. New Jersey: Englewood Clifs. 
International Journal of Human Capital Management, Vol. 1 (2), Desember 2017 